\section{Announcement of 2006 Annual Meeting}

$\mathrm{T}$

The Eighty-sixth Annual Meeting of The American Association for Thoracic Surgery will be held April 29-May 3, 2006, in Philadelphia, Pennsylvania, at the Pennsylvania Convention Center. The meeting of the Association is open to all physicians. House Officers and Fellows will be admitted without payment of a registration fee upon presentation of a letter from their Chief of Service either during preregistration or at the time of registration. Nonmember physicians are required to pay a $\$ 250$ preregistration fee up to March 24, 2006. After that date a registration fee of $\$ 300$ will be required. Members, nonmember physicians, and invited speakers will have the privilege of discussing papers.

\section{Requests for Preregistration Forms and Hotel Reservations}

Information on the 2006 Annual Meeting, including registration, hotel accommodations, and the social program, will be available in December 2005. Requests should be forwarded directly to:

American Association for Thoracic Surgery

900 Cummings Center

Suite 221-U

Beverly, MA 01915

978-927-8330; fax: 978-524-8890

e-mail: aats@prri.com

Registration and hotel information is available on our Web site at www.aats.org.

\section{Call for Abstracts}

Authors submitting abstracts for the 2006 Annual Meeting must use electronic submission. Abstracts submitted electronically for consideration for presentation at the 2006 meeting must have been received on or before October 10, 2005. Abstracts received after the deadline will not be considered by the Program Committee. The work must not have been presented or reported elsewhere.

\section{Electronic Submission}

Deadline for submission is October 10, 2005. Please submit your abstract via the World Wide Web. All abstract submissions must be in the structured format as required by The Journal of Thoracic and Cardiovascular Surgery. The structured abstract is to contain the following major headings: Objective(s), Methods, Results, and Conclusions, and it should clearly reflect the content of the completed paper. No reference should be made on the abstract to the names or institutions of the authors.

Receipt of each abstract will be acknowledged by e-mail. Notification of the decision of the Program Committee will be distributed by the end of December 2005.

Essayists selected for the program are reminded that papers presented at the meeting are to be submitted for consideration for publication to The Journal of Thoracic and Cardiovascular Surgery and must be submitted to the JTCVS via the Internet prior to the Annual Meeting. Papers that are selected by the AATS Program Committee may not be presented or published elsewhere prior to the Annual Meeting in 2006.

\section{Walton Lillehei Resident Forum}

The C. Walton Lillehei Resident Forum will be held on Sunday, April 30, 2006. Made possible through an educational grant from St Jude Medical, the Forum will consist of the presentation of original work by residents in thoracic surgical training programs around the world. Abstracts submitted for the award should follow the guidelines of abstract submission for electronic submission noted above. The abstracts submitted for consideration for this Forum will be evaluated by the Program Committee and eight will be selected for presentation during the forum. Each of the selected authors will receive round-trip travel and accommodations for the duration of the AATS annual meeting. Additionally, one presentation will be selected by the Program Committee to receive the AATS C. Walton Lillehei Residents' Award, a \$5000 prize. Thoracic Surgery Program Directors are urged to have their residents participate in this Forum.

Abstract Deadline-Abstracts received after the deadline will not be considered

Electronic Submission Only: October 10, 2005

\section{Applications for Membership}

Applications for membership in the Association must have been received by the Membership Committee Chairman no later than November 2005. Applications received after that date will be deferred automatically for consideration until the 2007 meeting.

Applications for membership may be issued to sponsoring members of the Association and are also available to potential candidates who have identified member sponsors. Application forms are available from:

\section{Chairman, Membership Committee}

American Association for Thoracic Surgery

900 Cummings Center

Suite 221-U

Beverly, MA 01915

978-927-8330; fax: 978-524-8890

e-mail: aats@prri.com

Irving L. Kron, MD, Secretary

\section{The Western Thoracic Surgical Association}

\section{Announcement of 2006 Annual Meeting}

$\mathrm{T}$ The Thirty-second Annual Meeting of The Western Thoracic Surgical Association will be held June 21-24, 2006, at the Sun Valley Resort in Sun Valley, Idaho. The scientific sessions are open to all duly qualified physicians. Participation in other Association activities for members, invited guests, and program participants will require payment of a social registration fee.

\section{Requests for Meeting Information}

Meeting preregistration and hotel registration forms will be available after January 2006 from: 
The Western Thoracic Surgical Association

900 Cummings Center

Suite 221-U

Beverly, MA 01915

978-927-8330; fax: 978-524-8890

wtsa@prri.com

\section{The American Board of Thoracic Surgery}

\author{
Notices
}

Scientific papers will be considered from members and nonmembers. Member sponsorship is not necessary.

For the 2006 Annual Meeting, abstract submission will open on November 14, 2005. All abstracts must be submitted electronically via the WTSA Web site. Information and a link to the submission site will be posted on the Web site on November 14. A Call for Abstracts will be mailed out around that time. Abstracts of proposed papers must be submitted on or before January 10, 2006.

Successful essayists must send the complete manuscript directly to The Journal of Thoracic and Cardiovascular Surgery and must not exceed 3000 words without illustrations. Electronic submissions are to be sent to: http://jtcvs.editorialmanager.com where complete instructions are also available. The essay length must be reduced appropriately when figures or tables are included.

\section{Samson Resident Prize Essay}

The Association offers a prize for the best manuscript on a topic of interest to thoracic surgeons in honor of Paul C. Samson, MD. Candidates for the prize must be in a training program in the United States or Canada. The one essayist whose abstract, manuscript, and presentation are judged most outstanding will receive a $\$ 2000$ cash award following the presentation of all papers in Sun Valley. The conditions for abstract submission, presentation, and publication as described above will apply. The authors of the abstracts chosen for the program will make up the finalists and will be notified by mid-February 2006 that they must submit six completed manuscripts for review by the Prize Essay Committee. The Prize Essay committee will make its selection following the presentation of all papers.

\section{Application for Membership}

Applications for membership in the Association must be received by the Membership Committee Chairman no later than March 1, 2006, to be considered at the following annual meeting. Applicants must be sponsored by three members of the Association who are not members of the Membership Committee. Application forms will be issued only to sponsoring members.

Address correspondence to:

Chairman, Membership Committee

The Western Thoracic Surgical Association

900 Cummings Center

Suite 221-U

Beverly, MA 01915

978-927-8330; fax: 978-524-8890

wtsa@prri.com

\section{Requirements for Recertification/Maintenance of Certification}

$\mathrm{D}$ iplomates of the American Board of Thoracic Surgery who plan to participate in the Recertification/Maintenance of Certification process must hold an active medical license and must hold clinical privileges in thoracic surgery. In addition, a valid certificate is an absolute requirement for entrance into the recertification/maintenance of certification process. If your certificate has expired, the only pathway for renewal of a certificate is to take and pass the Part I (written) and the Part II (oral) certifying examinations.

The American Board of Thoracic Surgery will no longer publish the names of individuals who have not recertified in the American Board of Medical Specialties directories. The Diplomate's name will be published upon successful completion of the recertification/maintenance of certification process.

The CME requirements include 70 Category I credits in either cardiothoracic surgery or general surgery earned during the 2 years prior to application. SESATS and SESAPS are the only selfinstructional materials allowed for credit. Category II credits are not allowed. The Physicians Recognition Award for recertifying in general surgery is not allowed in fulfillment of the CME requirements. Interested individuals should refer to the Booklet of Information for a complete description of acceptable CME credits.

Diplomates should maintain a documented list of their major cases performed during the year prior to application for recertification. This practice review should consist of 1 year's consecutive major operative experiences. If more than 100 cases occur in 1 year, only 100 should be listed. 